\title{
GLOSSARY OF TERMS
}

\author{
Armée d'Afrique the army of French North Africa, including French \\ cavalry units (chasseurs d'Afrique), North African \\ cavalry units (Spahis), French infantry units \\ (Zouaves), North African infantry (tirailleurs), units \\ of Moroccan irregulars (Goums), and Foreign Legion \\ regiments. \\ bey \\ beylical \\ cadi (qadi) \\ caïd \\ Caliph \\ caza \\ cercle \\ la Coloniale \\ colony \\ commandant \\ de cercle \\ dahir \\ dar al-Islam \\ Destour \\ djemâa \\ effendiyya \\ évolué \\ reigning prince of the Husaynid dynasty in Tunisia, \\ formerly subordinate to the Ottoman Sultan. \\ pertaining to the administration of Tunisia's \\ monarch, or bey. \\ a magistrate or judge of Shar'ia Law. \\ tribal representative or administrator. \\ usually refers to the Moroccan or Ottoman Sultan as \\ successor to the Prophet Mohammed. \\ administrative districts in Lebanon and Syria. \\ colonial administrative district, headed by a French \\ district officer. \\ the French colonial army after 1900, apart from \\ forces raised in French North Africa. Largely made up \\ of professional metropolitan regiments (Coloniale \\ Blanche) and colonial infantry regiments (tirailleurs). \\ I have tried to limit use of the word 'colony' to those \\ territories that were directly administered as colonies, \\ as opposed to as protectorates or mandates. On \\ occasion, however, I have used the term more \\ generically to denote any of France's overseas \\ dependencies, and to indicate that all were colonially \\ subjugated. \\ French colonial district officer. \\ decree legislation passed by the Moroccan Sultanate. \\ the Islamic world. \\ the Arabic term for 'constitution', and the title \\ adopted by the Tunisian Constitutionalist Party. \\ village assembly in colonial Algeria. \\ educated urban middle class in Arab cities, often \\ junior officials. \\ a colonial subject that had received a European-style
}


education, often employed as a government clerk or junior official. Évolués were in the forefront of demands for citizenship.

fellah peasant farmer.

goum

habous

harka

Hijaz

indigénat

Istiqlal

khalifa

khammès

khodja

Ky

lang do

lazaretto

Maghreb

makhzen

marabout

medersa

(madrasa)

métis(se)

métissage

mukhtar

natalité

a small force of Moroccan irregular infantry, typically numbering 150-75 men.

property or land bequeathed for a religious or charitable purpose.

an organised military force.

the western region of the Arabian peninsula.

colonial legislative code that empowered French regional officials to punish colonial subjects with fines or a short prison sentence without recourse to trial.

Arabic for independence. A title adopted by nationalist parties in Syria and Morocco.

a caïd's representative.

In French North Africa the term denotes a sharecropper, nominally allocated twenty per cent of the produce farmed in return for his labour.

a clerk. Typically refers to junior clerical staff in the French North African administration.

appellation for the Vietnamese territories of Tonkin (Bac Ky), Annam (Trung Ky) and Cochin-China (Nam Ky).

refers to the so-called 'red villages' loyal to the ICP during the Nghê Tinh revolt in 1930. isolation hostel for bubonic plague victims. collective term for the countries and region of North West Africa; used here to denote Morocco, Algeria and Tunisia.

the collective term for the Moroccan government and its administrative services.

Muslim holy man, typically the local leader of a religious sanctuary, or zawiya.

a religious school of advanced Muslim learning, often linked to a mosque.

offspring of mixed-race parents.

miscegenation, or the interbreeding of people classified as members of different racial groups. Muslim village headman.

the birth rate. Hence in post-First World War France 
pro-natalism denoted active political support for measures to increase the population.

navétanes seasonal economic migrants from the French West African interior working in the Senegal peanut basin.

originaires French African citizens born, or with parents born, in one of Senegal's 'original' Four Communes of SaintLouis, Rufisque, Dakar and Gorée.

pasha urban administrator of the Moroccan Sultanate.

prestation

Sahel

sanjak

Sharif

sheikh

spahi

Sufism

tariqa

tirailleurs a defined period (typically eight to ten days) of forced labour on designated colonial public works projects, usually road construction.

In Arabic, literally 'shore': denotes the regions immediately south of the Sahara.

Ottoman administrative sub-district of a vilayet, hence 'the sanjak of Alexandretta' in French Syria. a leader directly descended from the Prophet Mohammed.

the leader of a tribal fraction, a recognised elder, or the head of a religious institution such as a zawiya. French North African cavalry of the Armée d'Afrique. Islamic mysticism, often associated with a revered saint.

a Muslim religious brotherhood.

literally, riflemen. Usually applied to Coloniale infantry, hence tirailleurs sénégalais, referring to West African infantry units.

ulama a recognised Koranic teacher.

vilayet (in Turkish, wilayet)

Ottoman province.

zawiya

a Sufi Muslim religious institution, based around the tomb of a saint and sometimes including a school and/or hospice. 